\title{
Pengendalian Urban Sprawl Di Wilayah Pinggiran (Studi Kasus: Perkembangan Kota Di Indonesia Dan Perancis)
}

\author{
Nurazizah Ramlan' , Iwan Rudiarto²
}

Diterima : 6 Juli 2015

Disetujui : 31 Desember 2015

\begin{abstract}
The progress in urbanization within downtown areas has been expanded to the surrounding areas (i.e. periphery). This has been considered by the changes of the land uses in two geographically different countries. These areas have experienced a phenomenon of space consumption due to the urban development, which eventually triggered the urban sprawl, such as Mlati in Indonesia, Vertou, Caquefou and Sainte Luce Sur Loire in Nantes, France. This present study aims to examine the practices in the management of space consumption by urbanization in several municipals within periphery of Nantes, such as Carquefou, Sainte Luce sur Loire, Vertou and to compare with the sub-region of Mlati, in Sleman, Indonesia. The objective of this research was to answer the question; what are the major factors that influence the implementation of the policy controlling the urban sprawl in the periphery, in Indonesia and in France? These factors were decomposed in four components: regulations, institutions, resources and implementation. The approaches used in this study were, first of all, the quantitative method and based on its results. The second approach was done by descriptive qualitative method. The first approach was analysis of changes in land uses using evolution matrices of the change of land use, in order to study how a particular type of land use evolved and how it changed. The second step was done by an interview with the people key who are mastering the research subject, and then SWOT analysis was done from the interview. The results show that there is a significant difference between Indonesia and France, particularly in the human resources and implementation.
\end{abstract}

Keywords: Land use changes, urban development, urban sprawl, densification

\section{ABSTRAK}

Pertumbuhan urbanisasi di pusat kota meluas ke wilayah pinggiran. Ini terlihat dengan perubahan penggunaan lahan yang terjadi di dua negara yang secara geografis berbeda. Beberapa daerah telah mengalami fenomena konsumsi ruang oleh pembangunan perkotaan yang memicu terjadinya urban sprawl seperti Kecamatan Mlati di Indonesia, Kota Vertou, Kota Carquefou dan Kota Sainte Luce Sur Loire di Perancis. Penelitian ini bertujuan untuk mengkaji praktek pengelolaan konsumsi ruang oleh urbanisasi di beberapa kota di pinggiran Nantes, seperti kota Carquefou, kota Sainte Luce sur Loire dan kotaVertou dan kemudian membandingkannya dengan Kecamatan Mlati Kabupaten Sleman, Indonesia. Penelitian ini juga bertujuan untuk menjawab pertanyaan: faktor apa, di Indonesia dan Perancis, yang mempengaruhi pelaksanaan kebijakan pengendalian urban sprawl di wilayah pinggiran. Faktor yang akan kaji dibagi menjadi empat bagian, peraturan, kelembagaan, sumber daya manusia dan pelaksanaan. Pendekatan yang digunakan dalam penelitian ini adalah metode kuantitatif pada langkah pertama dan langkah kedua dilakukan dengan metode deskriptif kualitatif. Langkah pertama adalah analisis perubahan penggunaan lahan yang dibuat dengan matriks perubahan penggunaan lahan untuk mengetahui bagaimana perubahan suatu jenis penggunaan lahan tertentu dan kearah penggunaan lahan yang mana? Langkah kedua dilakukan dengan wawancara dengan narasumber yang menguasai subjek penelitian dan kemudian hasilnya di buat dalam tabel analisis SWOT. Hasil penelitian menunjukkan bahwa terdapat perbedaan yang signifikan antara Indonesia dan Perancis, khususnya dalam faktor sumber daya manusia dan pelaksanaan peraturan.

Kata kunci: Perubahan penggunaan lahan, pembangunan perkotaan, urban sprawl, densifikasi

\footnotetext{
1 Pemerintah Daerah Jayawijaya

Kontak penulis: Elly_ramlan@yahoo.com

2 Dosen Magister Pembangunan Wilayahdan Kota, Undip Semarang, Jawa Tengah
} 


\section{PENDAHULUAN}

Menurut data PBB, pertumbuhan populasi dunia terus meningkat. Pertumbuhan penduduk paling tinggi akan terjadi di negara-negara berkembang (Kompas, 2013). Indonesia merupakan negara berkembang. Menurut data dari BPS dan BAPPENAS negara ini memiliki 206.3 juta penduduk pada tahun 2000, jumlah itu meningkat sebesar $15 \%$ mencapai 237.600 .000 jiwa pada tahun 2010. Sementara itu, Perancis sebagai negara maju memiliki kecenderungan pertumbuhan penduduk yang meningkat secara teratur. Pada tahun 2014 populasi penduduk Perancis adalah 65.241.241 dan berdasarkan data proyeksi populasi dari INSEE pada 1 Januari 2050 penduduk perancis akan mencapai 70,0 juta.

Pertumbuhan populasi ini telah memberikan kontribusi pada peningkatan intensitas perubahan bentuk dan penggunaan lahan daerah (Leonataris: 2012), khususnya pada daerah perkotaan. Pembangunan perkotaan telah menyebabkan kejenuhan daerah pemukiman dan memicu arah penyebaran penduduk terutama ke sekitar daerah pinggiran (Sukamdi dkk, 1992). Peningkatan urbanisasi di Nantes Métropole dan Sleman Yogyakarta mendorong terjadinya urban sprawl. Padahal adanya kerangka legislatif, seperti RTRW di Indonesia dan undang undang Grenelle 1 dan 2, scot dan PLU di Perancis mendorong manajemen ruang yang efisien dan melawan urban sprawl.

Sleman dan Nantes Métropole dua wilayah yang telah mengalami fenomena konsumsi ruang oleh pembangunan perkotaan yang memicu urban sprawl. Pertumbuhan demografi di daerah pinggiran di kedua wilayah tersebut adalah yang paling dinamis dan yang paling berkontribusi pada terbentuknya lahan terbangun. Fenomena ini menimbulkan sejumlah masalah yang berkaitan dengan keterbatasan wilayah kota. Pertumbuhan urbanisasi ini telah terjadi dengan mengorbankan penggunaan lahan yang lain. Urbanisasi besar-besaran di pinggiran perkotaan mengakibatkan konsumsi daerah pertanian dan alam.

Menghadapi tantangan pertumbuhan penduduk yang tinggi dan persaingan pada sumber daya tanah yang tidak terbarukan, sangat penting untuk membuat kebijakan perencanaan wilayah, penghematan konsumsi ruang dan kepadatan yang akan memungkinkan kita untuk memperkaya perdebatan. Terutama program-program perencaan kota saat ini dan untuk ke depan yang mampu memenuhi keseimbangan pertumbuhan dengan potensi dan ketersediaan sumber daya yang ada, dan jauh dari urban sprawl tersebut. Sebagaimana kota-kota di Nantes metropolé yang memiliki dokumen perencanaan untuk mengelola konsumsi ruang, Sleman juga memiliki dokumen perencanaan yang disebut RTRW. Namun, meskipun konsep bentuk perkotaan dan pembangunan berkelanjutan sekarang diakuisisi secara bersama oleh tokoh protagonis kota; pengembangan tidak terkendali di daerah pinggiran kota mengungkapkan ketidakmampuan pejabat terpilih untuk melaksanakan rekomendasi pemerintahan (Andreault 2013). Penelitian ini bertujuan untuk menjawab pertanyaan: Apa sajakah faktor- faktor di Indonesia dan Perancis yang mempengaruhi pelaksanaan kebijakan pengendalian urban sprawl di wilayah pinggiran?

\section{METODE PENELITIAN}

Metode yang digunakan dalam penelitian ini adalah metode sequensiel. Metode ini dilakukan dengan menggabungkan metode kuantitatif pada langkah pertama dan kemudian berdasarkan hasil yang ditemukan, dilanjutkan langkah kedua yang dilakukan dengan metode deskriptif kualitatif (Creswell, 2009). Selain itu, dalam penelitian ini kami memilih studi kasus karena kami 
berniat untuk mengeksplorasi proses, kegiatan dan acara. Studi kasus adalah studi yang mengeksplorasi secara rinci masalah, mengumpulkan sejumlah data, dengan berbagai sumber informasi.

Ada dua jenis data yang disusun: data primer (penelitian dasar) sebagai citra satelit, foto udara, BD MOS 44, hasil wawancara dan data sekunder (data literatur) seperti data penggunaan lahan, dokumen rencana pembangunan, data INSEE. Langkah pertama adalah analisis perubahan penggunaan lahan. Hal ini dilakukan dengan overlay peta tutupan lahan tahun 1999 dan peta tutupan lahan pada 2009 untuk mengetahui lokasi perubahan penggunaan lahan secara spasial. Dalam hal ini, kita menggunakan data BD MOS44 yang menggambarkan penggunaan lahan yang sebenarnya dari klasifikasi hirarkis dalam 3 tingkat, dan lebih rinci. Untuk tahap kedua, kami akan melakukan wawancara dengan para pejabat ahli yang terkait dengan subjek penelitian saya. Mereka adalah pejabat pemerintah / pemerintah daerah dan badan-badan terkait pengendalian konsumsi ruang dan dokumen perencanaan (DTA, SCOT dan PLU). Kemudian untuk mengumpulkan data sekunder kita akan membuat kajian antara realitas empiris dan teori yang diperlukan dari dokumen, laporan, catatan, file atau dokumen tertulis lainnya yang bersifat resmi.

\section{RUANG LINGKUP WILAYAH STUDI}

Nantes Metropole merupakan gabungan 24 kota dan lebih dari 602.923 penduduk pada tahun 2012. Lebih dari setengah dari wilayahnya terdiri dari daerah alam atau pertanian dan $30 \%$ dari wilayahnya adalah perkotaan (Auran, 2015). Carquefou, Sainte Luce sur Loire dan Vertou dipilih sebagai wilayah penelitian karena merupakan kota- kota yang berbatasan langsung dengan Pusat Kota Nantes yang mengalami pertumbuhan permukiman paling menarik di Nantes Metropole.

Kecamatan Mlati merupakan kecamatan administratif kabupaten Sleman, Provinsi Yogyakarta, Jawa. Kabupaten Sleman yang ibukotanya adalah Sleman merupakan salah satu kabupaten di Provinsi Yogyakarta, dengan penduduk yang relatif besar dibandingkan dengan kabupaten lain di Provinsi Yogyakarta. Kabupaten Sleman memiliki luas 574,82 km2, atau 18\% dari wilayah provinsi Yogyakarta. Kabupaten ini mencakup 17 kecamatan: Gamping, Godean, Moyudan, Minggir, Segeyan, Mlati, Depok, Berbah, Prambanan, Kalasan, Ngemplak, Ngaglik, Sleman, Tempel, Turi, Pakem dan Cangkringan.

\section{KAJIAN PUSTAKA}

Kota memiliki sifat yang dinamis, tidak statis. Artinya kota akan mengalami perkembangan dari waktu ke waktu. Menurut Raharjo (1982), perkembangan kota didefinisikan sebagai perubahan yang dialami oleh daerah perkotaan pada aspek-aspek kehidupan dan penghidupan kota tersebut, dari tidak ada menjadi ada, dari sedikit menjadi banyak, dari kecil menjadi besar, dari penggunaan ruang sedikit menjadi teraglomerasi secara luas dan seterusnya. Yunus (1987) mendefinisikan perkembangan kota sebagai suatu proses perubahan keadaan ke keadaan lainnya dalam kurun waktu yang berbeda. Variabel yang mempengaruhi dalam perkembangan kota baik secara langsung maupun tidak langsung menurut Raharjo (1982) antara lain:

1. Penduduk : keadaan, proses dan lingkungan sosial penduduk.

2. Lokasi yang strategis: pusat Kota umumnya terletak di bagian tengah suatu wilayah kota, sehingga aksesibilitasnya tinggi. 
3. Fungsi kawasan perkotaan: fungsi dominan yang mampu menimbulkan perkembangan yang cepat, secara internal dan eksternal.

4. Kelengkapan sarana dan prasarana transportasi: untuk meningkatkan akses ke segala arah.

5. Faktor kesesuaian lahan: suatu output hasil superimpose kondisi fisik wilayah yang ada.

6. Faktor kemajuan dan peningkatan bidang teknologi: yang mempercepat proses pusat kota mendapatkan perubahan yang lebih maju.

Perubahan penggunaan lahan adalah bertambahnya suatu penggunaan lahan dari satu sisi penggunaan ke penggunaan yang lainnya diikuti dengan berkurangnya tipe penggunaan lahan yang lain dari suatu waktu ke waktu berikutnya, atau berubahnya fungsi suatu lahan pada kurun waktu yang berbeda (Wahyunto dkk, 2001). Perubahan penggunaan lahan pada umumnya dapat diamati dengan menggunakan data spasial dari peta penggunaan lahan pada titik tahun yang berbeda. Data penginderaan jauh seperti citra satelit, radar dan foto udara sangat berguna dalam pengamatan perubahan lahan.

Wilayah peripheri menjadi pilihan menetap bagi banyak orang dengan beberapa alasan seperti yang dijelaskan oleh Sternberg (2003) bahwa orang orang memiliki keinginan untuk menikmati suasana "kota kecil", mereka cenderung memilih hidup di daerah pinggiran. Untuk berbagai alasan, kehidupan di luar kota mewakili, dalam banyak hal, terutama kualitas hidup yang lebih baik. Perkembangan perkotaan yang terjadi di pinggiran kota akan berdampak pada pertumbuhan kebutuhan perumahan.

Menurut Certu (2010) sprawl adalah subjek dari banyak definisi, implisit atau eksplisit, yang sering mencerminkan pandangan penulis pada keinginan atau sebaliknya dari fenomena ini. Di AS, misalnya, istilah "urban sprawl" memiliki konotasi negatif. Di luar perpecahan ini, di Perancis, di bidang penelitian dan pemangku kepentingan publik, konsensus ada yang berakar pada teori ekonomi kota. Urban sprawl menggambarkan penyebaran spasial teratur atau tidak teratur dari pusat kota pada sebuah perkotaan, batas spasial lebih tinggi terhadap pertumbuhan penduduk yang menggambarkan kepadatan rata-rata masih rendah dari penduduk perkotaan.

\section{ANALISIS PERUBAHAN PENGGUNAAN LAHAN}

\section{Sainte-Luce sur Loire}

Pada tahun 1999, penggunaan lahan permukiman menempati lahan seluas 333 ha, atau $27 \%$ dari luas wilayah Sainte-Luce. Luas tersebut meningkat 25\% antara tahun 1999 dan 2009 yaitu dari 333 ha di 1999 menjadi 416 ha pada tahun 2009. Peningkatan ini juga terkait dengan pertumbuhan penduduk kota yang meningkat 3,7\% antara tahun 1999 dan 2009 dari 11498 menjadi 11929 jiwa. Penggunaan terbesar kedua adalah padang rumput alami seluas 212 ha (17\%). Yang ketiga berhubungan dengan kegiatan dan fasilitas seluas 113 ha (9\%). Penurunan terbesar selama periode ini meliputi penggunaan lahan oleh lingkungan vegetasi semak dan / atau herba. Ini menurun 62\%, atau 65 ha. Penurunan terbesar kedua berhubungan penggunaan lahan terbangun lainnya, yang mengalami penurunan sebesar 49\% (48 ha), seluas 51 ha. Yang ketiga adalah penggunaan lahan tanaman permanen yang menurun sebesar 26 ha (25\%), dari 105 ha di 1999 menjadi 79 ha pada tahun 2009.

\section{Carquefou}

Pada tahun 1999, 25\% dari luas wilayah kota Carquefou merupakan padang rumput alam seluas 1.081 ha. Penggunaan lahan terbesar kedua berhubungan dengan tanah subur, yang menempati 
20\% dari luas wilayah kota tersebut. Peningkatan paling signifikan antara tahun 1999 dan 2009 adalah peningkatan daerah oleh tanah yang subur. Penggunaan lahan ini meningkat seluas 175 ha, dari 883 ha di tahun 1999 menjadi 1.057 ha pada tahun 2009, atau meningkat 20\% dari total luasnya. Perubahan terbesar kedua ditempati oleh penggunaan lahan untuk kegiatan dan peralatan. Luas penggunaan lahan ini adalah 330 ha pada tahun 1999. Luas penggunaan lahan ini meningkat $29 \%$, atau 95 ha sehingga luasnya menjadi 425 ha pada tahun 2009. Perubahan penggunaan lahan ketiga adalah penggunaan lahan permukiman dimana pada tahun 1999, luasnya adalah 617 ha. Pada tahun 2009, itu merupakan 694 ha dan meningkat sebesar 13\%, atau 77 ha. Penurunan penggunaan lahan yang paling terlihat, selama periode ini, adalah padang rumput alami. Pada tahun 1999, luasnya adalah 1.081 ha. Penggunaan lahan ini menurun 35\%, dari 384 ha. Penurunan terbesar kedua (16\%, atau 22 ha) meliputi semak belukar seluas 135 ha pada tahun 1999 menjadi 114 ha pada tahun 2009. Yang ketiga adalah penurunan dari lahan basah. Penggunaan lahan ini menurun seluas 4 ha (9\%), pada tahun 1999 luasnya adalah 41 ha menjadi 38 ha pada tahun 2009.

\section{Vertou}

Pada tahun 1999, 23\% dari luas wilayah kota Vertou ditempati oleh daerah penggunaan lahan permukiman. Penggunaan lahan terluas kedua berhubungan dengan tanaman permanen, sampai $20 \%$. Yang ketiga adalah penggunaan lahan padang rumput alami, sampai $17 \%$. Peningkatan paling signifikan antara tahun 1999 dan 2009 adalah penggunaan lahan permukiman yang meningkat dari 888 ha di 1999 menjadi 969 ha pada tahun 2009 atau meningkat $9 \%$ dari luas awalnya. Perubahan penggunaan lahan terbesar kedua tampak pada penggunaan lahan untuk aktivitas dan peralatan. Luas penggunaan lahan ini adalah 172 ha pada tahun 1999 dan meningkat 24\% atau 41 ha sehingga menjadi seluas 213 ha pada tahun 2009. Perubahan ketiga berkaitan dengan penggunaan lahan oleh padang rumput alami. Pada tahun 1999 luasnya 658 ha dan pada tahun 2009 menjadi 685 ha atau meningkat $4 \%$ (27 ha). Sedangkan penggunaan lahan yang berkurang, paling besar selama periode ini adalah penggunaan lahan pertanian. Pada tahun 1999, luas lahan tersebut adalah 303 ha yang menurun 18\% (247 ha). Penurunan terbesar kedua ( $5 \%$ atau $41 \mathrm{ha}$ ) adalah penggunaan lahan tanaman permanen yang menempati 758 ha pada tahun 1999 sehingga tersisa 717 ha pada tahun 2009. Penurunan terbesar ketiga yang diamati adalah pengurangan signifikan dari penggunaan lahan semak belukar. Penggunaan lahan ini menurun 33 ha (19\%) dimana luasnya adalah 175 ha pada tahun 1999 menurun menjadi 142 ha pada tahun 2009.

\section{Mlati}

Pada tahun 1996, penggunaan lahan terbesar di Kecamatan Mlati adalah pertanian, seluas $1,803.40$ ha, atau $63,31 \%$ dari total luas kecamatan ini. Daerah pertanian terutama berlokasi di Mlati barat. Permukiman merupakan penggunaan lahan terluas kedua, yaitu 564,72 ha atau $19,82 \%$ dari total luas kecamatan, yang sebagian besar terletak di sebelah timur. Sementara, penggunaan lahan oleh daerah komersial, daerah basah, dan tempat rekreasi antara 1-5\% dari total wilayah Kecamatan Mlati. Penggunaan lahan hijau ruang, kantor, industri, terminal dan warisan budaya adalah kurang dari 1\%. Sementara penggunaan lahan pada tahun 2010 masih didominasi oleh lahan pertanian (1.512,73 ha), diikuti oleh daerah permukiman seluas 800,49 ha (Eko, 2012).

\section{Konsekuensi pertumbuhan perkotaan: konsumsi lahan pertanian dan alam}

Sprawl sering diterjemahkan sebagai perkembangan kota yang tidak teratur. Hal ini ditandai dengan pembangunan perkotaan yang tersebar ke segala arah. Perkembangan ini juga mengorbankan lahan yang berharga murah yang umumnya merupakan daerah pertanian yang terletak di pinggiran kota. Lahan pertanian banyak berubah menjadi permukiman, kantor dan 
pabrik. (Faturochman, 1990). Dampak yang paling penting dari pembangunan perkotaan dan urban sprawl terutama adalah pengurangan lahan pertanian dan daerah alam (Peta 1 dan peta 2). Pertumbuhan lahan permukiman terjadi dengan mengorbankan lahan pertanian dan alam. Penguatan gejala penggunaan lahan pertanian di pinggiran kota itu ditimbulkan dengan berkembangnya sistem transportasi -terutama oleh kemudahan memperoleh kendaraan - dan juga oleh perkembangan jalan tol. Dalam konteks Indonesia, pembangunan jalan akan selalu diikuti oleh perkembangan perumahan berdasarkan model "masyarakat kota line" (Faturochman 1990).
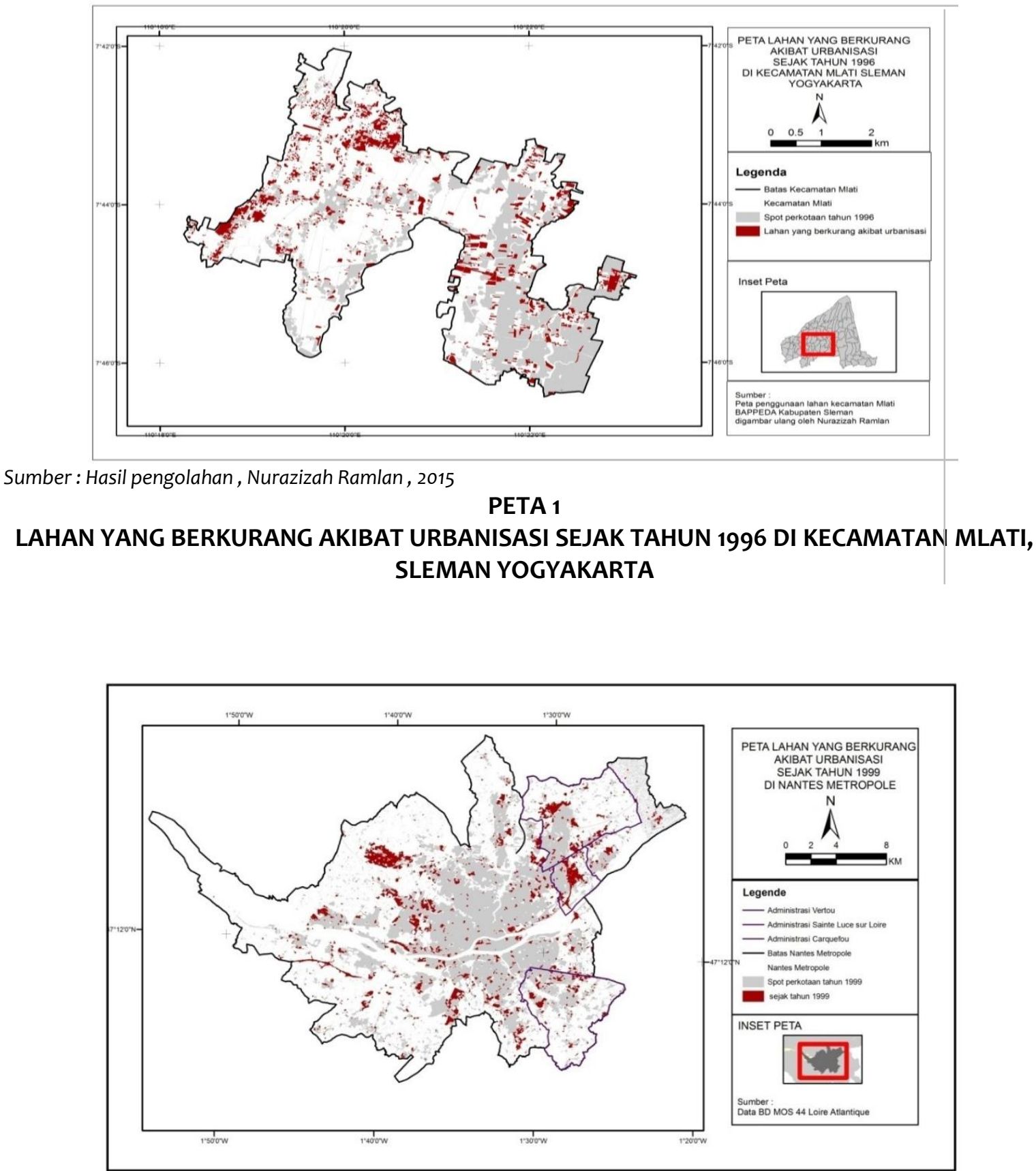

Sumber : Hasil pengolahan, Nurazizah Ramlan, 2015

PETA 2

LAHAN YANG BERKURANG AKIBAT URBANISASI SEJAK TAHUN 1999 DI NANTES METROPOLE 


\section{Vertou}

Sebesar 49\% dari penggunaan lahan di Vertou merupakan lahan pertanian, dimana $17 \%$ adalah kebun-kebun anggur seluas 640 ha. Tapi pada tahun 2009, luas kebun anggur turun $8 \%$ sehingga hanya menempati areal seluas 589 ha. Selain itu, pengurangan tampaknya terjadi juga pada luas lahan tanaman tahunan dan lahan yang subur, dari 303 ha pada 1999 menjadi 247 ha pada 2009, atau, mengalami penurunan seluas 56 ha (18\%).

\section{Carquefou}

Pada tahun 1999, lahan pertanian menempati 57\% dari total luas kota Carquefou, yaitu seluas 2465 ha. Sejak saat itu, lahan pertanian telah mengalami penurunan sebesar 4\%, atau seluas 178 ha. Selama sepuluh tahun, perubahan lahan tanaman tahunan dan lahan yang subur ditandai dengan peningkatan 175 ha dimana peningkatan terjadi pada lahan perkebunan dan hortikultura seluas 32 ha, untuk penelitian kehutanan dan pembibitan seluas 12 ha, dan untuk kehutanan dan peupleraies, dengan peningkatan 2 ha. Tapi perkembangan ini juga ditandai dengan penurunan $35 \%$ lahan padang rumput alami atau seluas 384 ha dan penurunan 16 ha untuk kebun-kebun anggur.

\section{Sainte-Luce-sur-Loire}

Lahan pertanian menduduki $28 \%$ dari luas wilayah kota pada tahun 1999. Sejak tahun 1999 hingga 2009 lahan pertanian mengalami penurunan sebesar 13\% (45 ha). Di Sainte-Luce, penurunan tersebut berhubungan dengan lahan semak dan atau herba. Sejak tahun 1999, lahan semak telah menurun 62\%, atau 65 ha yang terdiri dari : 51 ha untuk semak belukar, dan 14 ha untuk pembangunan kembali. Lahan pertanian yang mengalami penurunan adalah lahan yang diperuntukkan untuk berkebun dan hortikultura (31\%) atau 27 ha, tanaman tahunan dan tanah yang subur (31\%) selama 8 ha dan padang rumput alami seluas 11 ha (5\%) .

\section{Densifikasi permukiman}

Berdasarkan data dari BD MOS 44, kita dapat membandingkan dua pendekatan, baik penduduk kota terhadap luas total dari kota (peta 3 ) atau terhadap permukaan ruang terbangun (peta 4) (Chupin 2012 ). Chupin (2012) menemukan bahwa aglomerasi Nantes tampaknya lebih padat daripada yang lihat dari kepadatan ketat demografis. Kepadatan perkotaan diamati di daerah Nantes juga mengungkapkan model yang lebih bernuansa dan ditandai dengan gradien pusatpinggiran yang mengungkapkan kepadatan penduduk kotor, serta mencerminkan pola urbanisasi yang masih longgar di kota-kota tertentu. 


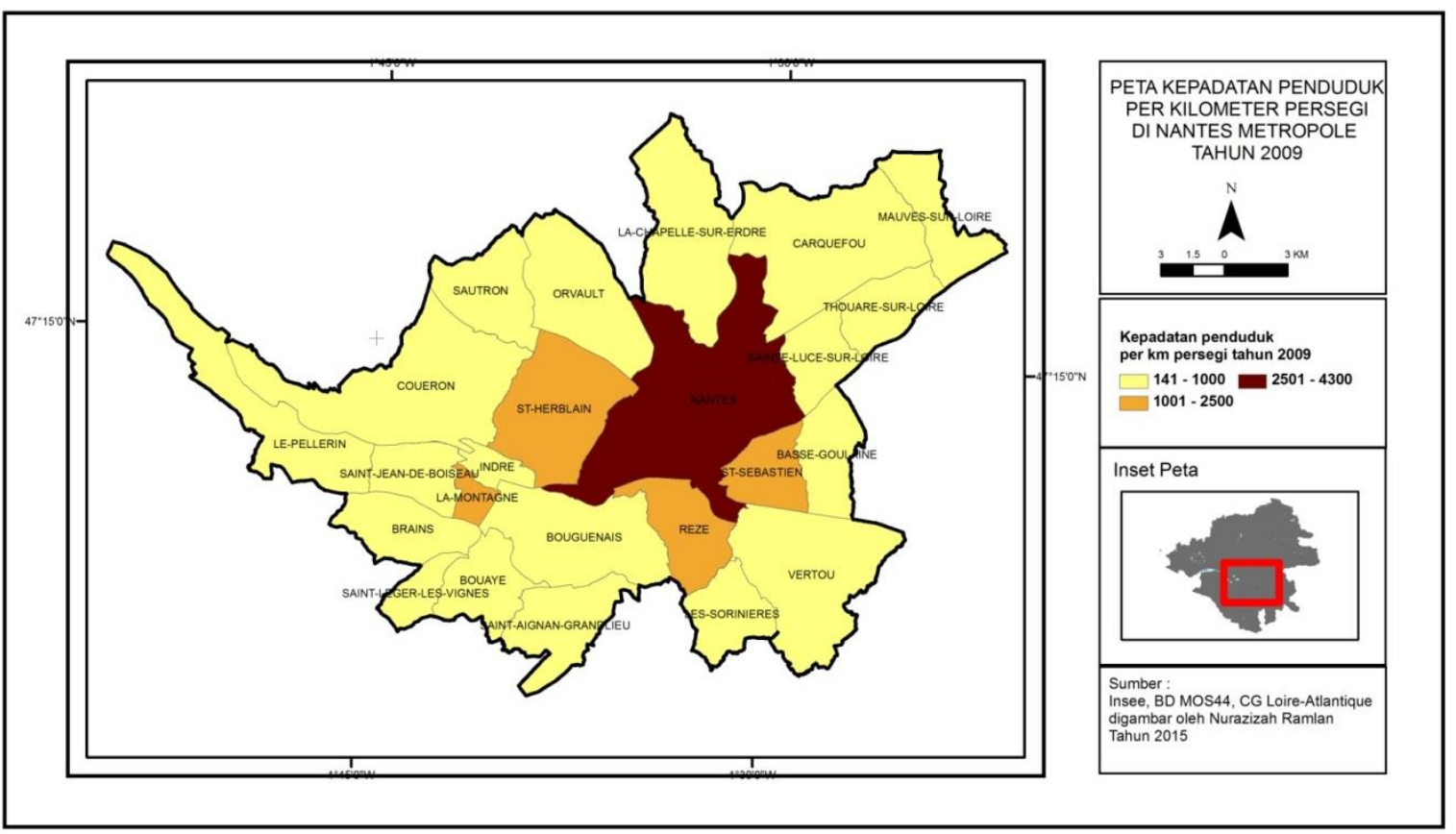

Sumber : Hasil pengolahan, Nurazizah Ramlan , 2015

\section{PETA 4}

KEPADATAN PENDUDUK DI NANTES METROPOLE PADA TAHUN 2009

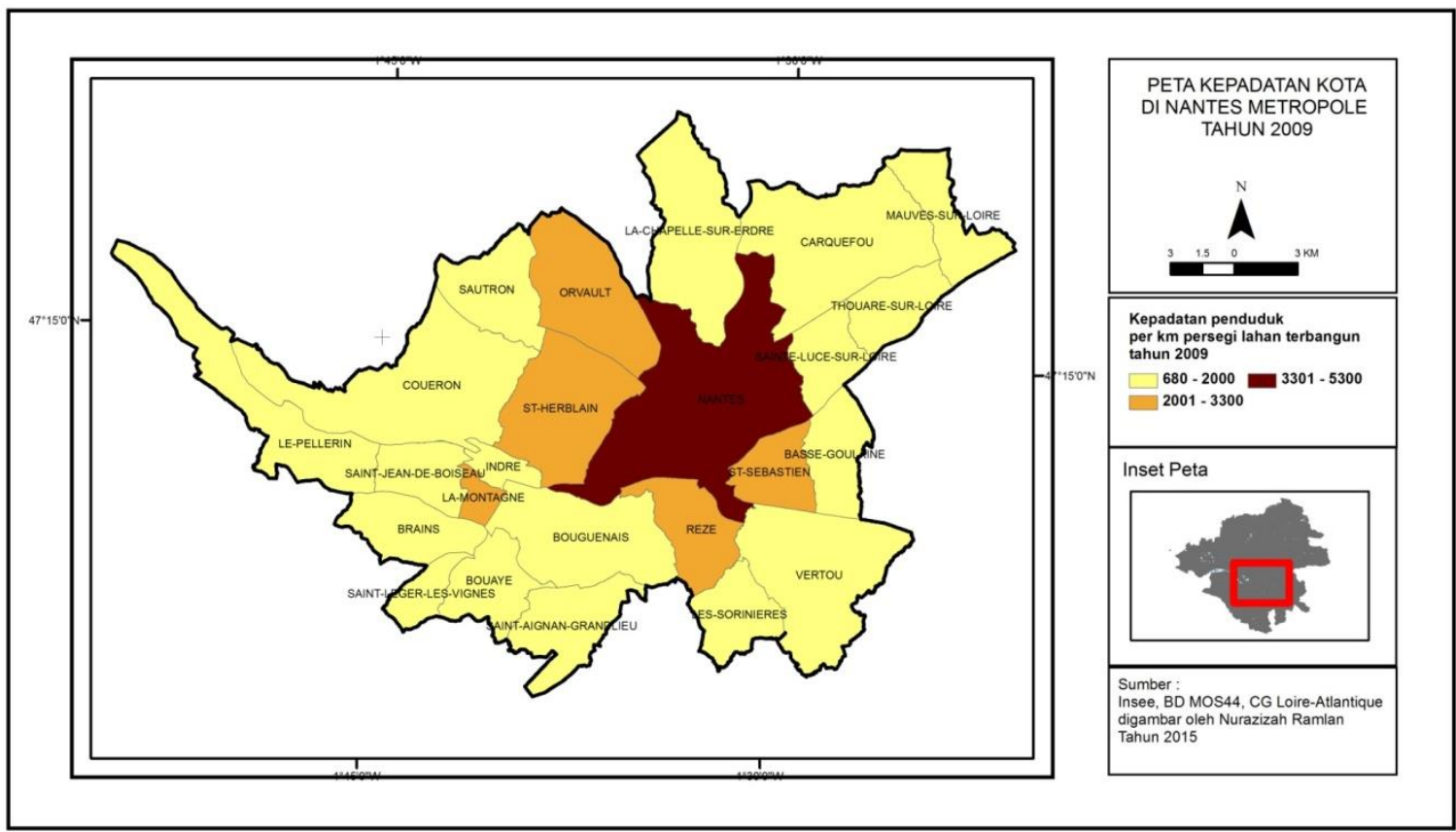

Sumber : Hasil pengolahan, Nurazizah Ramlan, 2015

\section{PETA 4}

KEPADATAN KOTA DI NANTES METROPOLE PADA TAHUN 2009

FAKTOR - FAKTOR YANG MEMPENGARUHI KEBIJAKAN PENGENDALIAN URBAN SPRAWL DI PERANCIS

Pelaksanaan peraturan penggunaan lahan Nantes Métropole dan Mlati sudah ada. Tidak ada hambatan dalam pelaksanaan kebijakan di bidang Nantes Métropole, tapi sebaliknya di kecamatan Mlati masih terdapat beberapa hambatan. Pelaksanaan kebijakan pengendalian 
urban sprawl di Nantes Métropole otomatis mengikuti apa yang telah ditetapkan dalam PLU. Hal ini dapat dilihat dalam tabel 1 faktor - faktor yang mempengaruhi kebijakan pengendalian urban sprawl di Perancis yang merupakan rangkuman hasil wawancara dengan beberapa pejabat terkait. Sedangkan di kecamatan Mlati, terdapat kelemahan dalam penerapan kebijakan yang diakibatkan karena kurangnya ketegasan dalam penindakan terhadap penggunaan dan perubahan penggunaan lahan yang melanggar aturan. Langkah yang dilakukan dalam perizinan, pengendalian dan pengawasan dilakukan sesuai dengan prosedur. Namun, penegakan hukum terhadap pelanggaran penggunaan lahan masih rendah. Hal ini sebagian disebabkan terbatasnya anggaran serta kurangnya pengawasan dan pengendalian atas penggunaan lahan.

TABEL 1

FAKTOR-FAKTOR YANG MEMPENGARUHI KEBIJAKAN PENGENDALIAN URBAN SPRAWL DI PERANCIS

\begin{tabular}{|c|c|c|c|c|c|}
\hline \multicolumn{6}{|c|}{ SWOT } \\
\hline & & Forces (S) & Faiblesses (W) & Opportunités (0) & Menaces $(\mathrm{T})$ \\
\hline \multirow{4}{*}{ 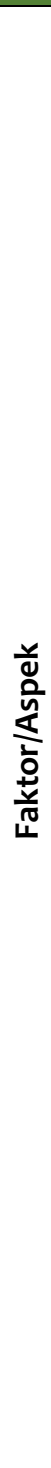 } & 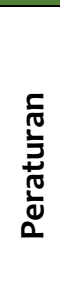 & $\begin{array}{l}\text { - Peraturan mengenai } \\
\text { perijinan dan } \\
\text { pengendalian } \\
\text { penggunaan lahan } \\
\text { sudah lengkap }\end{array}$ & $\begin{array}{l}\text { - Peraturan yang } \\
\text { ada membatasi } \\
\text { kreatifitas } \\
\text { arsitektur }\end{array}$ & $\begin{array}{l}\text { - Peraturan yang ada } \\
\text { sudah sangat efektif } \\
\text { - Terdapat program - } \\
\text { program yang } \\
\text { mendukung insentif } \\
\text { terhadap tanah } \\
\text { pertanian }\end{array}$ & $\begin{array}{l}\text { - } \text { Rencana } \\
\text { pemanfaatan lahan } \\
\text { berpotensi } \\
\text { menimbulkan } \\
\text { konflik terhadap } \\
\text { hak sipil seseorang } \\
\text { (hak pribadi) }\end{array}$ \\
\hline & 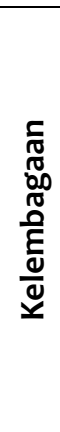 & $\begin{array}{l}\text { - Sudah terdapat } \\
\text { perangkat pelaksana } \\
\text { - Ada kerjasama yang } \\
\text { baik antar lembaga } \\
\text { dalam pengaturan } \\
\text { pemanfaatan ruang } \\
\text { - Perangkat pengawasan } \\
\text { berada pada tingkat } \\
\text { aglomerasi Nantes } \\
\text { Metropole }\end{array}$ & $\begin{array}{l}\text { - Kurangnya peran } \\
\text { perangkat kota. }\end{array}$ & $\begin{array}{l}\text { - Penggunaan } \\
\text { teknologi komputer } \\
\text { dan informasi } \\
\text { - Ketersediaan data } \\
\text { yang lengkap dan } \\
\text { akurat } \\
\text { Penyebaran } \\
\text { informasi lewat } \\
\text { internet sudah } \\
\text { efektif. }\end{array}$ & - \\
\hline & 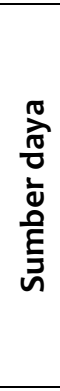 & $\begin{array}{l}\text { - Sumber daya manusia } \\
\text { memadai }\end{array}$ & $\begin{array}{l}\text { - Semangat } \\
\text { penegakan } \\
\text { hukum baik } \\
\text { - Pemahaman } \\
\text { masyarakat } \\
\text { tentang perijinan } \\
\text { perubahan } \\
\text { penggunaan } \\
\text { lahan sudah baik. }\end{array}$ & $\begin{array}{l}\text { - Kesadaran } \\
\text { masyarakat } \\
\text { terhadap perijinan } \\
\text { tata ruang sudah } \\
\text { baik. }\end{array}$ & - \\
\hline & 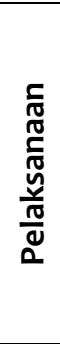 & $\begin{array}{l}\text { - Tahapan yang } \\
\text { dilakukan dalam } \\
\text { perijinan, pengendalian } \\
\text { dan pengawasan } \\
\text { dilaksanakan sesuai } \\
\text { dengan prosedur }\end{array}$ & $\begin{array}{l}\text { - Tindakan } \\
\text { terhadap } \\
\text { pelanggaran tata } \\
\text { rung sudah tegas } \\
\text { - Pengendalian } \\
\text { secara otomatis } \\
\text { sudah tersistem } \\
\text { oleh peraturan }\end{array}$ & $\begin{array}{l}\text { - Adanya undang- } \\
\text { unadang dan } \\
\text { peraturan yang } \\
\text { tersusun dengan } \\
\text { baik dan diatur } \\
\text { dengan baik. }\end{array}$ & $\begin{array}{l}\text { - Pengendalian } \\
\text { sudah berjalan } \\
\text { dengan baik. }\end{array}$ \\
\hline
\end{tabular}




\section{KESIMPULAN}

Kecamatan Mlati sebagai salah satu pinggiran Yogyakarta telah memperoleh pengaruh yang signifikan terutama dalam hal penggunaan lahan. Hal ini jelas dari persentase evolusi perubahan penggunaan lahan antara 1996 - 2010, yang mencapai 10,32\% dari total permukaan kecamatan ini. Hal yang sama terjadi pada beberapa kota di Nantes Metropole, seperti Vertou, Carquefou dan Sainte Luce sur Loire. Pembangunan perkotaan dari kota-kota ini telah dipengaruhi oleh pembangunan perkotaan kota Nantes. Perubahan penggunaan lahan permukiman antara 19992009 mengalami peningkatan yaitu Carquefou meningkat 77 ha, Sainte Luce sur Loire meningkat 83 ha dan Vertou meningkat 82 ha. Kemajuan pembangunan perkotaan terwujud dengan mengorbankan lahan pertanian dan alam di mana kebun-kebun anggur di Vertou berkurang 51 ha, lahan hortikultura dan berkebun pasar di Sainte Luce Sur Loire berkurang 26 ha, dan padang rumput alami di Carquefou berkurang 384 ha.

Nantes Métropole dan Mlati sama - sama telah memiliki perangkat peraturan yang mengatur mekanisme pengendalian urban sprawl. Peraturan perencanaan untuk mengontrol urban sprawl di Nantes Métropole adalah SCOT dan PLU. Sementara penerapan kebijakan PLH (Rencana Perumahan lokal) dilakukan untuk menyeimbangkan pasokan perumahan sewa. Peraturan perencanaan Nantes Métropole sangat efektif dalam wilayah mereka. Sementara di Mlati, dan RTRW dan RDTR adalah peraturan perencanaan untuk mengendalikan urban sprawl. Namun dalam praktek penerapannya di lapangan, kedua wilayah tersebut menghadapi hambatan dan kelemahan yang berbeda. Kecamatan Mlati cenderung mengalami hambatan yang lebih besar daripada wilayah Nantes Métropole. Langkah-langkah yang sebaiknya dilakukan sebagai perbaikan antara lain sebagai berikut:

a. Perlunya penyediaan data dan informasi potensi dan sumber daya lahan dengan lengkap, tepat dan akurat.

b. Mewujudkan studi tentang optimalisasi perencanaan penggunaan lahan, dimana penyusunan rencana dilakukan dengan menyesuaikan potensi lahan/wilayah.

c. Memperkuat fungsi kontrol dengan melakukan evaluasi secara berkala

d. Membuat kebijakan untuk memperbaiki kondisi dengan memperkuat penggunaan program ruang yaitu dengan menyesuaikan penggunaan rencana ruang yang telah ditentukan dengan model spasial.

e. Tindakan represif yang diambil sesuai dengan ketentuan hukum yang berlaku.

f. Penggunaan program harus sesuai dengan rencana tata ruang.

\section{DAFTAR PUSTAKA}

Andreault, Céline. 2013. Du Periurbain A L'urbain : Les outils de la densification des premieres couronnes périurbaines. Université Paul Valery Montpellier3.

Auran. 2008. Loire Atlantiquez008 : diagnostic du territoire departemental. Hal .131

Auran. 2015. Nantes Metropole chiffres et reperes. Population legales 2012.

CERTU. 2010. Le mode d'occupation du sol de l'aucame

CERTU. 2010. La consommation d'espaces par l'urbanisation, Panorama des méthodes d'évaluation

Creswell. 2009. Qualitative Research Introduction . Center for Teaching, Research \& Learning Research Support Group at the Social Science Research Lab American University, Washington, D.C. 
Chupin dan Pottier, 2012. 10 ans d'évolution de l'occupation du sol dans les territoires de LoireAtlantique (1999-2009), Les particularités locales face à la progression des espaces résidentiels. Cahier Nantaise. IGARUN

Eko Trigus. 2012. Perubahan Penggunaan Lahan dan Kesesuaiannya terhadap RDTR di Wilayah Peri-Urban Studi Kasus: Kecamatan Mlati . Jurnal Perencanaan wilayah dan kota . Planologi Undip.Semarang.

Sternberg dkk. 2003. L'impacts de l'étalement urbain. Forum environnement : développement urbain durable.

Sukamdi, Riyanto, dan Widaningrum Ambar. 1992. Analisis Dampak Kependudukan di Propinsi Jawa Barat. Yogyakarta: Pusat Penelitian Kependudukan Universitas Gadjah Mada.

Faturochman, Yogya post, 30-31 mei1990, Pertumbuhan Kota Yogyakarta. Kondisi Sosio-Psikologis Yogya Unik

Leonataris. 2012. Analisis Pola Perubahan Penggunaan Lahan dan Perkembangan Wilayah di Kota Bekasi . IPB

Raharjo. 1982. Perkembangan Kota dan Beberapa Permasalahannya. UGM , 1982

Wahyunto dkk,. 2001. "Studi Perubahan Lahan di Sub DAS Citarik, Jawa Barat dan DAS Kaligarang Jawa Tengah." Prosiding Seminar Nasional Multifungsi Lahan Sawah. Hal 39-40. Bogor 1 Mei 2001.

Yunus, Hadi Sabari, 1987. Permasalahan daerah urban fringe dan alternative pemecahannya.Yogyakarta:FakultasGeografi UGM

www.kompas.com , sabtu, 15 juni 2013. 